\title{
ORGANOTIN POLLUTION FROM PLEASURE CRAFT AT PARATY, A TOURIST AREA OF SOUTHEASTERN BRAZIL: AMELIORATION OR INTERFERENCE?
}

\author{
Camila de Leon Lousada Borges ${ }^{1, *}$, Marcos Antonio dos Santos Fernandez, \\ Ítalo Braga Castro ${ }^{2}$ and Gilberto Fillmann ${ }^{2}$ \\ ${ }^{1}$ Universidade do Estado do Rio de Janeiro \\ (Rua São Francisco Xavier, 524 sala 4018E, 20550-013 Rio de Janeiro, RJ, Brasil) \\ Universidade Federal do Rio Grande \\ Departamento de Oceanografia, Laboratório de Microcontaminantes Orgânicos e Ecotoxicologia Aquática \\ (Av. Italia, km 8, s/n, 96211-100 Rio Grande, RS, Brasil) \\ *Corresponding author: camiladeleon@gmail.com

\begin{abstract}
A B S TR ACT
Some organotin compounds, such as TBT, are endocrine disruptors and harm marine ecosystems. Even after the global ban on organotins, increasing imposex levels have been detected in Stramonita haemastoma analyzed in 2004 and 2011 in some locations at Paraty, a tourist area in southeastern Brazil. The results of this study indicate that particulate and dissolved organic carbon and xenoestrogens might be interfering in this syndrome's development, leading to underestimation of imposex evaluation. Chemical analysis of three mangrove swamp sediments in the area showed the presence of TBT (16.0 - 205.7 ng Sn g-1), DBT (10.1 - $16.4 \mathrm{ng}$ Sn g-1) and MBT (10.1 - $10.2 \mathrm{ng} \mathrm{Sn}$ $\mathrm{g}-1)$ even at the reference sites. The concentrations of butyltins and the increased incidence of imposexat some stations indicate recent inputs of TBT in the study area due to its illegal use on small vessels.
\end{abstract}

\section{RESUMO}

\begin{abstract}
Alguns compostos organoestânicos, como o TBT, são desreguladores endócrinos e causam danos aos ecossistemas marinhos. Mesmo após a proibição global de organoestânicos, níveis crescentes de imposex foram detectados em indivíduos Stramonita haemastoma analisados em 2004 e 2011, em Paraty, área turística no sudeste do Brasil. Os resultados deste estudo indicam que partículas e carbono orgânico dissolvido e xenoestrógenos podem estar interferindo no desenvolvimento dessa síndrome, levando à subestimação de avaliação do imposex. A análise química de três sedimentos de mangue na área mostrou a presença de TBT (16,0-205,7 ng Sn g-1), DBT (10,1-16,4 ng Sn g-1) e MBT (10,1-10,2 ng Sn g-1), mesmo nos locais de referência. As concentrações de butilestânicos e o aumento da incidência de imposex em algumas estações indicam entradas recentes de TBT na área estudada devido ao uso ilegal em pequenas embarcações.
\end{abstract}

Descriptors: Butyltins, Imposex, Stramonita haemastoma, Mangrove, Southeastern Brazilian coast, Temporal evolution.

Descritores: Butilestânicos, Stramonita haemastoma, Mangue, Costa Sudeste do Brasil, Evolução temporal.

\section{INTRODUCTION}

Antifouling paints are used to prevent growth of fouling organisms on surfaces submerged in water, especially vessel and boat hulls. Among the biocides used in the last decades of the twentieth century, tributyltin (TBT) was considered the most successful in avoiding biofouling on vessels (LEWIS, 1998; YEBRA et al., 2004). It was also, however, the most problematic due to damage caused to non-target organisms. It is widely known that organotin compounds (OTs) can cause endocrine disruption in marine animals such as gastropods, bivalves and cephalopods (FERNANDEZ et al., 2007; SIAH et al., 2007; ORTIZ; RÉ, 2006). Moreover, several studies have shown that these compounds can damage the reproductive and immune systems of aquatic mammals (HOCH, 2001; KANNAN et al., 1996). They can also be bioconcentrated and biomagnified 
along the marine trophic chains (STRAND; JACOBSEN, 2005; MURAI et al., 2008), which may pose a threat to human populations that feed frequently on seafood (CHIEN et al., 2002; FERNANDEZ et al., 2005a; NAKANISHI, 2007; ANTIZAR-LADISLAO, 2008; SANTOS et al, 2009).

The best known effect of this compound is called imposex, a syndrome of endocrine disruption that causes the superimposition of male characters such as penis and/or vas deferens in female marine gastropods (SMITH, 1971). Imposex has been observed globally, with recorded cases in the North Sea, Atlantic Ocean and Mediterranean Sea in Europe, as well as along the coasts of the United States, Japan, India, Australia, Chile and Brazil (see discussion in SONAK et al., 2009). The Antarctic region is the only one that does not have any record of imposex. Endocrine disruption has been described in more than 260 species of gastropods, although a wide range of responses has been observed even among species of the same genus. (TITLEY-O'NEAL et al., 2011; STROBEN et al., 1995). Imposex is a worldwide biomarker for biomonitoring the effects of organotin pollution (MATTHIESSEN; GIBBS, 1998; MORCILLO; PORTE, 2000; OEHLMANN et al., 2007; CASTRO et al., 2012c) and its incidence is inversely related to the distance from sources of OTs, such as ports, marinas and shipyards (FERNANDEZ et al., 2005b; SHI et al., 2005).

The International Marine Organization (IMO, 2001) through the International Convention on the Control of Antifouling Systems on Ships (AFS) has established a global ban on antifouling paints based on organotin compounds since September 2008. Fortyfive countries, representing $74 \%$ of the world fleet, are signatories to the convention and pledged to ban the application of tributyltin (www.imo.org). Although many developed countries had adopted measures to restrict the use of organotin compounds long before the ban came into force and reduced concentrations of tributyltin in their ecosystems (GALANTEOLIVEIRA et al., 2009; MORTON, 2009), some other countries still have areas affected by these compounds (BIGATTI et al., 2009; GUOMUNDSDOTTIR et al., 2011; TOSTE et al., 2011; FURDEK et al., 2012; MARTI et al., 2011). Despite this, only a few countries' have actually published any results of the monitoring programs of these compounds in their marine environment. In 2003, the MARINHA DO BRASIL (2007) banned the use of tributyltin-based paints on its own vessels, and a national ban was established in 2007 (NORMAN 23 - Ordinance No. 76/DPC of July 30, 2007). However, despite the ban, both tributyltin oxide and chloride are still being produced and sold in Brazil (CASTRO et al., 2012b). Since the IMO (2001) ban does not prohibit either the production or the sale of organotin compounds - only their application for antifouling purposes (SONAK et al., 2009) - they can be sold freely in and to countries that do not restrict their use (for example, China, Pakistan, Taiwan, Korea). Another problem is the general lack of guidelines in these countries for the safe disposal of organotin-based paints. Shipyards may function as sources of these compounds to the aquatic environment even after the local enforcement of the ban on their application (KOTRIKLA, 2009; SONAK et al., 2009).

Within this scenario, the aim of this study was to assess organotin pollution before and after the national and international bans on TBT in a region where the marine traffic is only characterized by the presence of small boats and repair yards, (Paraty-RJ, southeastern Brazil), being far from other known organotin source areas, as part of a project that evaluates the effectiveness of control measures in Brazil.

\section{Material and Methods}

Study Area and Sampling

This study was conducted in the Paraty region $\left(23^{\circ} 13^{\prime} 04^{\prime \prime S} / 44^{\circ} 42^{\prime} 47^{\prime \prime} \mathrm{W}\right.$, Fig. 1a) during the summers of 2004 and 2011. This area is characterized by some intensive maritime activities involving only leisure boats. This area has neither big shipyard nor commercial terminal, and is not close to the main shipping lanes of Ilha Grande bay, where these activities are important and organotin pollution has previously been reported (PESSOA et al., 2009; FERNANDEZ et al., 2007). Approximately 750 small boats currently occupy the two main local marinas and the public tourist pier of Paraty, most of them being moored there throughout the year. Two small boat repair yards are also located in this area, just between the local marinas and the public pier (Fig. 1b, c, photos 1 and 2). This area is, thus, highly suitable for the study of the occurrence and effects of the biocides used on small boats as antifouling paints.

The sampling stations and methodology were the same during both the 2004 (SILVA et al., 2007) and the 2011 studies, except for stations A8 and A10 which were sampled only in 2004. Briefly, 30 sexually mature specimens of the species Stramonita haemastoma were collected by snorkeling at each station. In the laboratory, the animals were anesthetized in a $1: 1$ solution of $7 \% \mathrm{MgCl}_{2}$ in distilled water and sea water from the collection site for at least an hour. After the narcotization, the animals had part of the palial cavity exposed, and the palial organs of the reproductive tract were observed by gently pulling the animals body out of the shell, without breaking it. In males and females, the occurrence of penis, pre- 
penis or vas deferens was observed beside the right tentacle. After the anatomical analysis, narcotization was reversed with seawater from the sampling site and the animals returned to their places of origin. Unlike the conventional method of analysis of imposex, in which the shells are broken, causing the death of the animals, the non-destructive method does no damage to the organism and thus preserves the populations (FERNANDEZ et al., 2007). The anatomical data obtained were treated as follows: females with signs of imposex and males were considered statistically as "male" and only completely healthy females were considered in the test as "female." Hereupon, the probability "P" of a sample with "n" healthy females among $\mathrm{N}$ animals (in this case, $\mathrm{N}=30$ ) was calculated for each station sampled based on a population binomially distributed and balanced sexually, which is the case for the species tested. $\mathrm{p}$ and $\mathrm{q}$ being the probabilities respectively associated with males and females, it is to be expect that $\mathrm{p}=0.5$ and $\mathrm{q}=0.5$ in healthy populations of Stramonita. There are two main sources of variability in population sex ratios: low sample size (n) and endocrine disruption, which masculinizes females. To distinguish the effects of these two sources, the following criteria were adopted: the site is considered impacted if $\mathrm{P}<0.001$ and is considered potentially impacted if $0.001<\mathrm{P}<0.05$ and the site is considered not impacted if $\mathrm{P}>0.05$. In this last case, the variability is only attributed to normal variation in each sample due to the small sample size (FERNANDEZ et al., 2007).

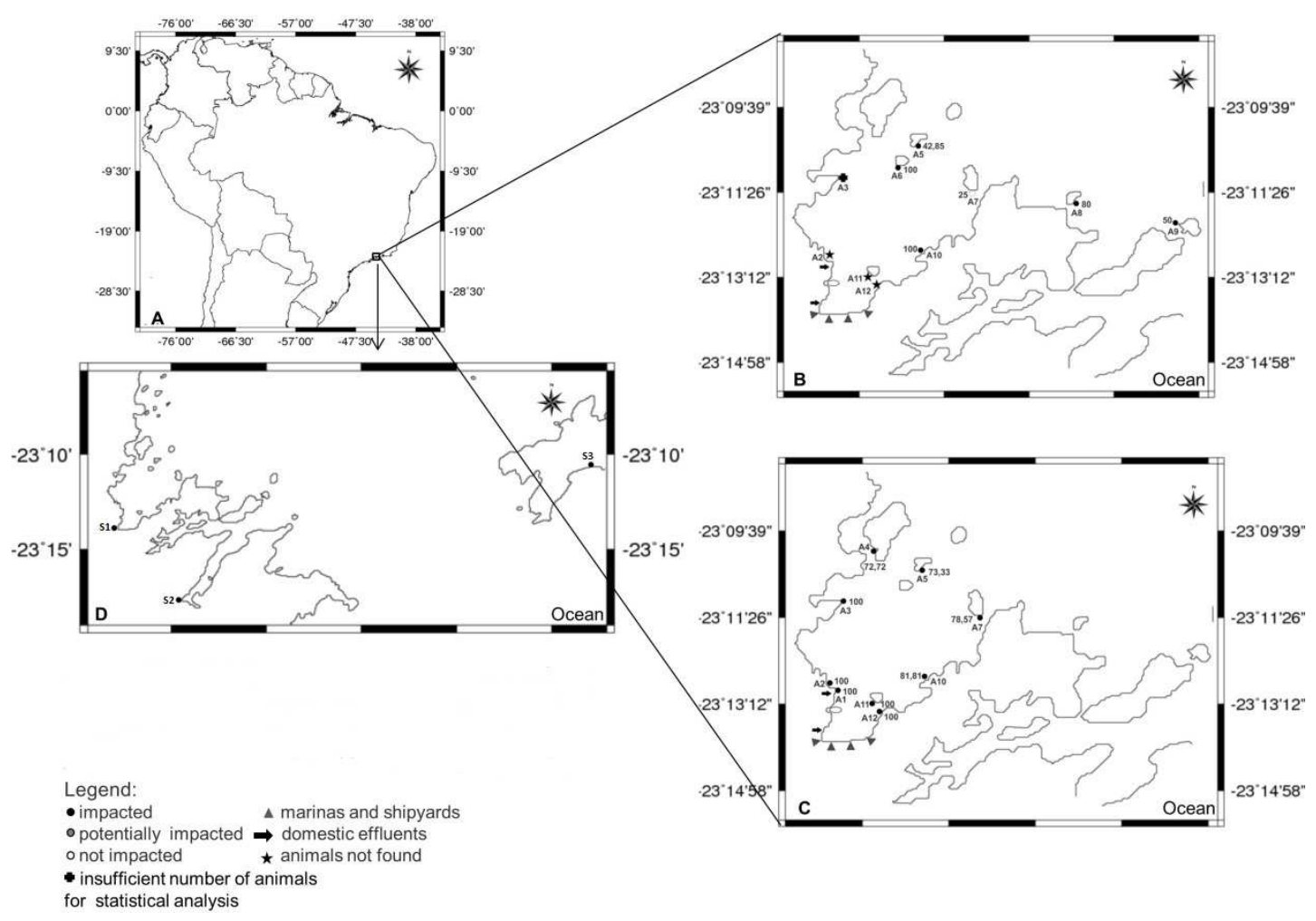

Fig. 1. Map showing the study area of Paraty. (A) Distribution of percentual of imposex affected females (\%I) and respective statistical evaluation in 2005. (B) The same for 2011. (C). Location of sediment sampling stations in Paraty (S1 and S2) and Ilha Grande (S3) in 2011 (D). 


\section{Sediment Butyltin Speciation Analysis}

Triplicate surface sediment samples were collected from three sampling areas: the small residual mangrove swamp between the artisanal shipyards and the biggest marina on the inner Paraty inlet ( $\mathrm{S} 1$,

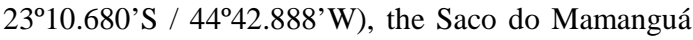
mangrove swamp, a well-preserved mangrove swamp in the Paraty region but far removed from the city and its antifouling sources (S2, 2317'269's / $44^{\circ} 39^{\prime} 138^{\prime \prime} \mathrm{W}$ ) and the Aventureiro beach mangrove swamp, on Grande Island, considered to be one of the best preserved areas on the Rio de Janeiro coast, located south of Ilha Grande island and facing the

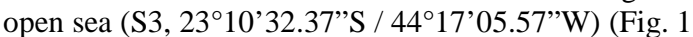
d). The last two stations are among those considered to be the best preserved on all the southeastern Brazilian coast, with no dwellings (Aventureiro) or very few (Mamanguá) and accessible only by boat or on foot. In this study, these were taken as the control stations while S1, close to the main antifouling sources, was presumably the most impacted location on the Paraty inlet. Briefly, butylated organotins were determined following the procedure given by Castro et al. (2012a). An exact mass $(\sim 5 \mathrm{~g})$ of dry sediment of each sample was extracted (3 times) by sonication with $15 \mathrm{ml}$ of tropolone solution $(0.05 \% \mathrm{w} / \mathrm{v})$ in methanol and $1 \mathrm{ml}$ of concentrated $\mathrm{HCl}(37 \%)$ after fortification with 100 ng of tripropyltin (surrogate). Supernatants were transferred to a $250 \mathrm{ml}$ separatory funnel filled with $150 \mathrm{ml}$ of a $10 \% \mathrm{NaCl}$ solution and extracted 3 times with dichloromethane. This extract was collected through anhydrous sodium sulphate and added to $5 \mathrm{ml}$ of hexane. Extracts were concentrated down to $2 \mathrm{ml}$ by rotary evaporation at $40^{\circ} \mathrm{C}$. Derivatization was done by pentylation using n-pentyl magnesium bromide in diethyl ether solution. The excess Grignard reagent was destroyed with $15 \mathrm{ml}$ of ultrapure water and $1 \mathrm{ml}$ of concentrated $\mathrm{HCl}(37 \%)$ in an ice bath. Derivatized organotins were extracted with $5 \mathrm{ml}$ of hexane (3 times), and then blown down to $0.5 \mathrm{ml}$ under nitrogen flow. Extracts were transferred to the top of a silica gel column ( $3.5 \mathrm{~g})$ previously wettened with hexane-toluene (1:1) and eluted in $15 \mathrm{ml}$ of this solution. The extracts were concentrated down to 0.9 $\mathrm{ml}$ under nitrogen, and $1000 \mathrm{ng}$ tetrabutyltin was added as internal standard. Butyltins were determined in a Perkin Elmer Clarus 500MS gas chromatograph equipped with a mass spectrometer detector, using an Elite-5MS (5\% diphenyl/95\% dimethylpolysiloxane) capillary column $(30 \mathrm{~m}$ x $0.25 \mathrm{~mm}$ I.D., $0.25 \mu \mathrm{m}$ film thickness). Quality assurance and quality control were based on regular analyses of blanks, spiked matrices and certified reference material (PACS-2 / National Research Council of Canada, Ottawa, Canada). Results obtained for the PACS-2 (TBT $-798 \pm 23 \mathrm{ng}$ $\mathrm{Sn} \mathrm{g}^{-1}, \mathrm{DBT}-1104 \pm 12 \mathrm{ng} \mathrm{Sn} \mathrm{g}^{-1}$ and MBT $-670 \pm 20$ ng Sn $\mathrm{g}^{-1}$ ) were in good agreement with the certified (TBT - 890 $105 \mathrm{ng} \mathrm{Sn} \mathrm{g}^{-1}$ and DBT $-1047 \pm 64 \mathrm{ng}$ $\mathrm{Sn} \mathrm{g}^{-1}$ ) and reported values (MBT - $600 \mathrm{ng} \mathrm{Sn} \mathrm{g}^{-1}$ ). The samples recoveries were between 95.2 and $100.9 \%$ and RSD (relative standard deviation) below $20 \%$ (IUPAC, 2002). All concentrations were reported as $\mathrm{ng} \mathrm{Sn} \mathrm{g} \mathrm{g}^{-1}$ (dry weight) and degradation ratios were expressed as TBT/DBT+MBT concentrations (CASTRO et al., 2012a; RUIZ et al., 2010).

\section{RESULTS}

In the 2004 study at Paraty the presence of Stramonita heamastoma was not observed at stations $\mathrm{A} 2$, A11 or A12 (Table 1). These stations were located on the innermost part of Paraty inlet, close to the marinas and small shipyards. At station A3, farther from this area on the northern shore, the animals were present but in insufficient numbers for statistical analysis $(\mathrm{N}=16)$. However, all the females of this small population presented imposex $(\mathrm{N}=7)$ (Table 1). From this part of the inlet outwards, a decline in imposex intensity was observed. During the 2011 study, S. heamastoma populations were detected at all of these sites (Fig. 1c, Table 1) and at all the stations a severe imposex development was observed, all females in the inner stations showing the syndrome. Thus, regarding the distribution of the gastropod populations in the study area, an improvement in organotin pollution was observed.

On the other hand, and contrasting with this improvement, an increase in the intensity of imposex was observed at the stations closer to the mouth of the inlet, from $25 \%$ imposexed females in 2004 to $78.6 \%$ at station A5 in 2011 and from $42.9 \%$ imposexed females in 2004 to $73.3 \%$ at station A7 in 2011 (Fig. 1 b,c, Table 1). Station A7, for instance, not considered impacted in 2004, was considered as statistically impacted in 2011 (Fig. 1 b,c, Table 1). Seen thus, the pollution has become more intense and has not been reduced at a distance from the sources as was to have been expected.

Chemical analysis of surface sediments confirmed that extensive organotin pollution is occurring throughout the area. On the inner inlet, organotin mean concentrations in the small, degraded mangrove swamp near the shipyard (S1), were 205.7 $+/-16.8 \mathrm{ng}(\mathrm{Sn}) \cdot \mathrm{g}^{-1}$ of TBT, $16.4+/-1.3 \mathrm{ng}(\mathrm{Sn}) \cdot \mathrm{g}^{-1}$ of DBT and $10.0+/-2.9 \mathrm{ng}(\mathrm{Sn}) . \mathrm{g}^{-1}$ of MBT, corresponding to a degradation ratio of 7.84 , one of the highest recorded in Brazil. At the two control stations, organotin concentrations were: $16.0+/-0.8$ $\mathrm{ng}(\mathrm{Sn}) \cdot \mathrm{g}^{-1}$ of TBT, $10.1+/-1.4 \mathrm{ng}(\mathrm{Sn}) \cdot \mathrm{g}^{-1}$ of DBT and $10.1+/-2.2 \mathrm{ng}(\mathrm{Sn}) \cdot \mathrm{g}^{-1}$ of MBT on the inner part of Mamanguá inlet; and $18.1+/-4.2 \mathrm{ng}(\mathrm{Sn}) \cdot \mathrm{g}^{-1}$ of TBT, $15.3+/-0.5 \mathrm{ng}(\mathrm{Sn}) \cdot \mathrm{g}^{-1}$ of DBT and $10.2+/-1.5$ 
$\mathrm{ng}(\mathrm{Sn}) \cdot \mathrm{g}^{-1}$ of $\mathrm{MBT}$ at the Aventureiro mangrove swamp. Degradation ratios were 0.79 and 0.71 respectively.

Table 1. Stations sampled in Paraty with their percentage of imposex and year of sampling.

\begin{tabular}{lll}
\hline Stations & $\begin{array}{l}\text { Year/Percentage } \\
\text { of imposex (I\%) }\end{array}$ & $\begin{array}{l}\text { Year/Percentage } \\
\text { of imposex (I\%) }\end{array}$ \\
\hline A1 & 2004 & 2011 \\
A2 & NF & 100 \\
A3 & IN & 100 \\
A4 & NS & 100 \\
A5 & 42.8 & 72.7 \\
A6 & 100 & 73.3 \\
A7 & 25 & NS \\
A8 & 80 & 78.6 \\
\hline
\end{tabular}

$\mathrm{NF}=$ animals not found; $\mathrm{IN}=$ animals in insufficien numbers for statistical analysis; $\mathrm{NS}=$ animals not sampled.

\section{DisCUSSION}

The results obtained in Paraty showed a different pattern than what would be expected after the TBT ban. In 2004, at the points located nearby the main sources of antifoulings (marinas and small shipyards), the presence of the Stramonita heamastoma was not recorded (Table 1). At station A3, located inside the inlet but further away from the marinas, the animals were present but in insufficient numbers for statistical analysis and all the females showed imposex (Table 1). As $S$. heamastoma populations were detected in all of these sites during 2011 (Fig. 1c, Table 1), the observation indicates a recolonization on the part of these populations, which suggests an improvement in the environmental conditions regarding OT pollution on the inner inlet. This same pattern has been recorded in areas where populations of gastropods had become extinct due to organotin contamination but had recovered after reduction in the levels following national and international restrictions (MORTON, 2009; BIRCHENOUGH et al., 2002; CROTHERS, 2003). This recolonization has even been recorded for species such as Nucella lapillus (MORTON, 2009), which has a low dispersion capacity due to its direct development. The planktonic larval stage makes it easier for Stramonita haemastoma to recuperate previously damaged populations (SPENCER et al., 1990).

Organotin mean concentrations measured in the inner mangrove swamp/forest (S1), close to the local sources, were $205.7+/-16.8 \mathrm{ng}(\mathrm{Sn}) \cdot \mathrm{g}^{-1}$ of TBT, $16.4+/-1.3 \mathrm{ng}(\mathrm{Sn}) \cdot \mathrm{g}^{-1}$ of DBT and $10.0+/-2.9 \mathrm{ng}$ (Sn). $\mathrm{g}^{-1}$ of MBT, not as high as those previously reported for some stations in Guanabara Bay by Fernandez et al., (2005b), but higher than those of most stations analyzed in this highly polluted region. In should be noted that the samples were collected at the external mangrove swamp fringe, in shallow, aerated water. These conditions are favorable to the fast degradation kinetics of organotins. However, the degradation ratio value of 7.84 indicates the recent introduction of these compounds into this area, which confirms that organotin compounds were still being used in the small craft present in the inlet. For comparison, Fernandez et al. (2005b) have found values ranging from $520.9 \mathrm{ng}$. $\mathrm{g}^{-1}$ (TBT) to 394.6 $\mathrm{ng}(\mathrm{Sn}) \cdot \mathrm{g}^{-1}$ (DBT) and MBT was not detected, concentrations being less than $4.7 \mathrm{ng}(\mathrm{Sn}) \cdot \mathrm{g}^{-1}$ on Botafogo inlet, close to Rio de Janeiro Yatch Club, one of the most contaminated areas of Guanabara bay. In these highly anoxic sediments, the organotin degradation ratio was 1.32 , an indication of a slow degradation. This observation further accentuates the contradictory character of the biological monitoring observations in this study, since a relatively high concentration of organotins was present in the area and there has been recent input. These observation was further reinforced by the detection of organotins at both the control stations, where it was not expected to find them. In these cases, degradation ratios were higher, as expected, because of a much lower number of boats in each area, and the absence of repair activities. Despite the low levels and ratios, it should be noted also that these were surface sediments collected at the fringe of the mangrove swamp, in very shallow and well oxygenated waters (10-15 $\mathrm{cm})$. Under these conditions, TBT degradation could be fast indeed, which may also indicate, though to a lesser extent, recent use by the small boat traffic at each of these places (RUIZ et al., 2010; GARG et al., 2011). Thus, chemical evidence indicates that organotin pollution seems to be widespread in the whole study area.

So why did biological effects seem to be reduced at the inner stations, as indicated by the recolonization of the populations in the inner inlet, while the outer stations' populations showed an increase in the biological response to pollution?

In our opinion, there are at least two hypotheses that could explain these observations. First, it is possible that the animals simply were not detected at the stations closer to the sources in 2004 due to the high water turbidity. This seems, however, 
very unlikely, since isolated animals were found at at least one station at that time, and the sampling effort was the same. The second hypothesis is that OT availability might be affected by the organic matter and other contaminants present in domestic effluents.

For instance, the study area has no domestic effluent treatment of any kind, these effluents being released "in natura" into the inlet by the drainage channels close to the city (the main outlets are marked by small arrows in Figures $1 \mathrm{~b}$ and c). This sewage load has increased considerably during the study period, since the population of Paraty grew from 23,928 inhabitants in 1991 to 29,544 inhabitants in 2000 and 37,533 inhabitants in 2007 (IBGE, 2011), an increase of $57 \%$ in less than 20 years. In addition, a further increase in the population is seen during the tourist season, especially during summer time when the samples were collected. The sewage load can contribute to the increased particulate and dissolved carbon content of the waters close to the city's historic center, where the population has the biggest growth. Furthermore, the mangrove swamps of the region also contribute with high levels of particulate and dissolved organic matter (KRISTENSEN et al., 2008; SCHAEFER-NOVELLI et al., 2000). Some of these mangrove areas are located close to the city and upstream of the inlet's main drainage channels, the very same channels that receive untreated domestic wastewater. It is widely known that organic carbon is one of the strongest complexing agents for organotins (LANGSTON; POPE, 1995; VOULVOULIS; LESTER, 2006). The large load of organic matter may reduce the availability of OTs to the biota in the area closer to the sources of domestic effluent, which in this very particular case are almost coincident with the location of the main tributyltin sources (Fig.1 b, c). Another possible source of interference in the development of imposex is the presence of natural and synthetic xenoestrogens in the sewage (as estrogen, estradiol, estrone, estriol, bisfenol A, phthalates (LaFLEUR; SCHUG, 2011; WISE et al., 2011). These compounds may interfere in the study results by reducing the degree of masculinization in females exposed to tributyltin, because they have an antagonistic effect on imposex development, as demonstrated in bioassays by Santos et al., (2008). These compounds are also ubiquitous in the environment, as a very recent study has demonstrated by the striking observation that plasma vitellogenin levels of male teleost fishes (an estrogenic activity indicator) in 43 rivers worldwide correlated with the numbers of human populations upstream (DESFORGES et al., 2010). Estrogenicity has been demonstrated for many taxa such as bivalve and gastropod mollusks, crustaceans, fishes, amphibians, reptiles and mammals (PAMPANIN et al., 2005; OEHLMANN et al., 2000; RICCIARDI et al., 2008;
FERREIRA et al., 2009; HAYES et al., 2010; SOLOMON et al., 2008; BORNMAN et al., 2010).

While not determined in the 2004 study, organotin concentrations could have been even higher than today, considering the reduction in imposex response in some areas reported by other authors in Brazil (CASTRO et al., 2012b). In keeping with this line of thinking, there are three good sets of satellite images of Paraty inlet: for the years 2012, 2008 and 2003. While the number of boats was smaller by some $40 \%$ in the first set (2003), the number of piers and moorings was quite similar in the other two (2008 and 2012). On the other hand, organotin application was legal and easy at that time, though it is now officially forbidden in Brazil and organotin-free paints are available in the market. Thus, a lesser number of boats does not mean that there was a directly lesser organotin load some years ago. In that case, with less urban sewage and estrogens in the water, and perhaps even more organotins, the observed pattern would be exactly the same as was in fact observed then, that is, with a strong gradient of imposex severity overriding the interference mechanism by the simple force of the animals' body burden. The interference mechanism may reduce, but not eliminate, the imposex response, at least in the bioassay study (SANTOS et al., 2008).

Similar observations of a possible interference mechanism in imposex development have been made in recent studies undertaken along the Brazilian coast. Contradictory patterns, in which some animals with high concentrations of organotins in their tissues and low indexes of imposex development, have been observed elsewhere. For instance, $\Sigma$ OTs between 125 and $320 \mathrm{ng}(\mathrm{Sn}) \cdot \mathrm{g}^{-1} \mathrm{Sn}$ and VDSI values between 0.81 and 1.31 have recently been reported by Rossato (2010) for Stramonita haemastoma collected from five sites at São Francisco do Sul, SC, southern Brazil. The same species have shown much higher VDSI values (between 2.3 and 3.2) with much lower tissue concentrations of organotins ( $\Sigma$ OTs between 59.6 to $\left.80 \mathrm{ng}(\mathrm{Sn}) \cdot \mathrm{g}^{-1} \mathrm{Sn}\right)$, as observed by Limaverde et al. (2007) during a bioassay experiment undertaken at Arraial do Cabo, RJ, southeastern Brazil. Limaverde et al. (2007) also analysed imposex intensity and organotin concentrations in a field imposex intensity gradient, and found $\Sigma$ OTs between $23.7 \mathrm{ng}(\mathrm{Sn}) \cdot \mathrm{g}^{-1}$ and $62.9 \mathrm{ng}(\mathrm{Sn}) . \mathrm{g}^{-1}$ while VDSI index values were between 2.2 and 3.1. In both cases, the response of the animals tested was much higher. It should be kept in mind, however, that even as the same species was tested in these studies, genetic differences may be present because the populations are located very far one from another, and genetic exchange is minimal. However, the results are contrasting, and the possibility of interference cannot be ruled out because of the different environmental conditions: while the 
first study occurred in an area under the strong influence of raw domestic sewage and presenting great turbidity in the water, the second study was carried out in very clear water and under the much weaker influence of such domestic effluents in Arraial do Cabo, while the field gradient was measured in stations close to the entrance of Guanabara Bay, where water quality is poorer, but organotin concentrations in the water were probably much higher.

This interference mechanism, while still somewhat speculative because no specific study was made on it, could then well explain why the points located close to the entrance of the inlet (stations A5 and A7) showed an increase in the intensity of imposex along the time interval of the study, while the inner stations showed a somewhat better condition. This could occur because the outer inlet area has less interference of organic matter in the bioavailability of tributyltin, since organic matter would suffer very rapid biochemical processes of oxidation as well as physical dispersion as it moves away from its sources, this reduction of the organic matter concentrations being evidenced by the change in color and transparency of the water observed in the area. The loss of the organic matter "buffer" could then leave organotins less complexed and more bioavailable, explaining the increase in imposex only at the more external stations (A5 and A7) of the Paraty inlet. It should also be pointed out that the same dispersion process would affect the xenoestrogens present in the water, thus reducing their antagonistic effect on organotins.

In any case, it should also be pointed out that all the internal stations at which the animals were not found in the 2004 sampling and where they were now found present $100 \%$ imposex in the females. The high incidence of imposex in the local females throughout the study area and the increase of imposex intensity in the outer inlet area indicate that organotin pollution still persists. The interference mechanism proposed here could even indicate that organotin pollution has intensified, as it has increased in the points furthest from the sources. This increase in the percentage of imposex between 2004 and 2011 also indicates that environmental and economic damage is occurring in the region, but due to the lack of basic ecotoxicological information on the local species, the extension of the damage could not be evaluated with certainty. It is known that TBT affects the immune and reproductive systems of several marine species (HOCH, 2001; PARK et al., 2012) and this may result in a reduction of populations of commercial value as well as in a reduction of local biodiversity. These results also indicate that despite the ban on tributyltin antifouling paints in Brazil, these compounds are being used illegally, at least on small boats. Surely, if a significant reduction in the use of organotin based antifouling paints had occurred in the area, the biological response would have been greatly reduced, as has been seen elsewhere (RUIZ et al., 2010, MORTON, 2009). The results of this study point decidedly to the need, in this area, of chemical analyses of organotins, particulate and dissolved organic carbon and xenoestrogens, since biomonitoring results alone are inconclusive and could suffer from chemical interference. The sampling of sediment cores in the area could also provide useful information on the history of the application of organotins in an area of typical small tourist boating activities.

The data obtained in this study will serve as a baseline for future studies on organotin pollution since the areas where high levels of imposex are being found nowadays indicate the most important areas for future monitoring of the effects of the new tributyltinfree antifouling paints on native marine communities (FERNANDEZ; PINHEIRO, 2007). Finally, the possibility of interference in a monitoring tool such as imposex clearly deserves specific study, because of the relevance of the application of this kind of study. Biomonitoring data without chemical information should be interpreted with care under certain conditions, as shown above, because the observations may underestimate the actual biological expression of organotin pollution.

\section{AcKNOWLEDGMENTS}

The authors thank the Brazilian Research Council (CNPq) for their financial support (482488/2010-4 for Marcos A. Fernandez and 382327/2011-0 for Gilberto Fillmann -PQ 314335/2009-9) and CEADS-UERJ for their logistical support. We also thank Mateus Parahyba, Pietro Fancinetti, Lívia Sant'Angelo, Bruno Costa, Ana Beatriz Ramos, undergraduate students of Oceanography-UERJ, for their help with the sampling.

\section{REFERENCES}

ANTIZAR-LADISLAO, B. Environmental levels, toxicity and human exposure to tributyltin (TBT)-contaminated marine environment: a review. Environ. Int., v. 34, n. 2, p. 292-308, 2008

BIGATTI, G.; PRIMOST M. A.; CLEDÓN, M.; AVERBUJ, A.; THEOBALD, N.; GERWINSKI, W.; ARNTZ, W.; MORRICONI, E.; PENCHASZADEH, P. E. Biomonitoring of TBT contamination and imposex incidence along $4700 \mathrm{~km}$ of Argentinean shoreline (SW Atlantic: from $38 \mathrm{~S}$ to $54 \mathrm{~S}$ ). Mar. Pollut. Bull., v. 58, n. 5, p. 695-701, 2009.

BIRCHENOUGH, A. C.; EVANS, S. M.; MOSS, C.; WELCH, R. Re-colonisation and recovery of populations of dogwhelks Nucella lapillus (L.) on shores formerly subject to severe TBT contamination. Mar. Pollut. Bull., v. 44, n. 7, p. 652-659, 2002. 
BORNMAN, M. S.; BARNHOORN, I. E. J.; DE JAGER, C; VEERAMACHANENI, D. N. R. Testicular microlithiasis and neoplastic lesions in wild eland (Tragelaphus oryx): possible effects of exposure to environmental pollutants? Environ. Res., v. 110, n. 4, p. 327-333, 2010.

MARINHA DO BRASIL. Diretoria de Portos e Costas. Normas da autoridade marítima para o controle de sistemas antiincrustantes danosos em embarcações: NORMAM-D23DPC: portaria n.76/DPC, de 30 de julho de 2007. Disponível em: https://www.dpc.mar.mil.br/normam/N23/normam23.pdf. Acesso em: 04 abr, 2011.

CASTRO, I. B.; ARROYO, M. F.; COSTA, P. G. FILLMANN. G. Butyltin compounds and imposex levels in Ecuador. Arch. Environ. Contam. Toxicol., v. 62, n. 1, p. 68-77, 2012a.

CASTRO, I. B.; PERINA, F. C.; FILLMANN, G. Organotin contamination in South American coastal areas. Environ. Monit. Assess., v. 184, n. 3, p. 1781-1799, 2012b.

CASTRO, I. B.; ROCHA-BARREIRA, C. A.; FERNANDEZ, M. A.; BIGATTI, G. Transplant bioassay induces different imposex responses in two species of the genus Stramonita. Mar. Biol. Res., v. 8, n. 4, p. 331-338, 2012c.

CHIEN, L. C.; HUNG, T. C.; CHAOANG, K. Y.; YEH, C. Y.; MENG, P. J.; SHIEH, M. J.; HÁ, B. C. Daily intake of TBT, $\mathrm{Cu}, \mathrm{Zn}, \mathrm{Cd}$ e As for fishermen in Taiwan. Sci. Total Environ., v. 285, n. 1/3, p. 117-185, 2002.

CROTHERS, J. H. Further observations on a population of dog-whelks, Nucella lapillus (Gastropoda) recolonizing a site following amelioration of tributyltin (TBT) pollution. J. Mar. Biol. Assoc. U. K., v. 83, n. 5, p. 1023-1027, 2003.

DESFORGES, J. P. W.; PEACHEY, B. D. L.; SANDERSON, P. M.; WHITE, P. A.; BLAIS, J. M. Plasma vitellogenin in male teleost fish from 43 rivers worldwide is correlated with upstream human population size. Environ. Pollut., v. 158, n. 10, p. 3279-3284, 2010.

FERNANDEZ, M. A.; PINHEIRO, F. M. New approaches for monitoring the marine environment: the case of antifouling paints. International Journal of Environment and Health, v.1, n.3, p.427-448, 2007.

FERNANDEZ, M. A.; PINHEIRO, F. M.; QUADROS, J. P.; CAMILLO Jr., E. An easy, non-destructive, probabilistic method to evaluate the imposex response of gastropod populations. Mar. Environ. Res., v. 63, n. 1, p. 41-54, 2007.

FERNANDEZ, M. A.; LIMAVERDE, A. M.; SCOFIELD, A. L.; WAGENER, A. L. R. Preliminary evaluation of human health risks from ingestion of organotin contaminated seafood in Brazil. Braz. J. Oceanogr., v. 53, n. 1/2, p. 75-77, 2005a.

FERNANDEZ, M. A.; WAGENER, A. L. R.; LIMAVERDE, A. M.; SCOFIELD, A. L.; PINHEIRO, F. M.; RODRIGUES, E. Imposex and surface sediment speciation: a combined approach to evaluate organotin contamination in Guanabara Bay, Rio de Janeiro, Brazil. Mar. Environ. Res., v. 59, n. 5, p. 435-452, 2005 b.

FERREIRA, F.; SANTOS, M. M.; CASTRO, L. F.; REISHENRIQUES, M. A.; LIMA, D.; VIEIRA, M. N.; MONTEIRO, N. M. Vitellogenin gene expression in the intertidal blenny Lipophrys pholis: a new sentinel species for estrogenic chemical pollution monitoring in the European Atlantic coast? Comp. Biochem. Physiol., Part C: Toxicol. Pharmacol., v. 149, n. 1, p. 58-64, 2009.

FURDEK, M.; VAHČIČ, M.; ŠČANČAR, J.; MILAČIČ, R.; KNIEWALD, G; MIKAC, N. Organotin compounds in seawater and Mytilus galloprovincialis mussels along the Croatian Adriatic Coast. Mar. Pollut. Bull., v. 64, n. 2, p. 189-199, 2012.

GALANTE-OLIVEIRA, S.; OLIVEIRA, I.; JONKERS, N.; LANGSTON, W. J.; PACHECO, M.; BARROSO, C. M. Imposex levels and tributyltin pollution in Ria de Aveiro (NW Portugal) between 1997 and 2007: evaluation of legislation effectiveness. J. Environ. Monit., v. 11, n. 7, p. 1405-1411, 2009.

GARG, A.; MEENA, R. M.; JADHAV, S.; BHOSLE, N. B. Distribution of butyltins in the waters and sediments along the coast of India. Mar. Pollut. Bull., v. 62, n. 2, p. 423-431, 2011.

HAYES, T. B.; KHOURY, V.; NARAYAN, A.; NAZIR, M.; PARK, A.; BROWN, T.; ADAME, L.; CHAN, E.; BUCHHOLZ, D.; STUEVE, T.; GALLIPEAU, S. Atrazine induces complete feminization and chemical castration in male African clawed frogs (Xenopus laevis). Proc. Natl. Acad. Sci. U. S. A., v. 107, n. 10, p. 46124617, 2010.

$\mathrm{HOCH}$, M. Organotin compounds in the environment an overview. Appl. Geochem., v. 16, n. 7/8, p. 719-743, 2001.

IBGE. Censo da população do município de Paraty, Rio de Janeiro, 2011. Disponível em: http://www.ibge.gov.br/home/estatistica/populacao/censo 2010/default.shtm. Acesso em: 10 dez. 2011.

IMO. Conventions. List of Conventions. International Convention on the Control of Harmful Antifouling Systems on Ships. 2001. Disponível em: http://www.imo.org/About/Conventions/ListOfConventi ons/Pages/International-Convention-on-the-Control-ofHarmful-Anti-fouling-Systems-on-Ships-(AFS).aspx. Acesso em: 7 jun. 2011.

IUPAC. Pure and Applied Chemistry., v. 74, p. 2169-2200, 2002.

KANNAN, K.; SENTHILKUMAR, K.; LOGANATHAN, B. G.; TAKAHASHI, S.; ODELL, D. K.; TANABE, S. Elevated accumulation of Tributyltin and its breakdown products in Bottlenose Dolphins (Tursiops truncatus) found stranded along the U.S. Atlantic and Gulf Coasts. Environ. Sci. Technol., v. 31, n. 1, p. 296-301, 1996.

KOTRIKLA, A. Environmental management aspects for TBT antifouling wastes from the shipyards. J. Environ. Manage., v. 90, suppl.1, p. 77-85, 2009.

KRISTENSEN, E.; BOUILLON, S.; DITTMAR, T.; MARCHAND, C. Organic carbon dynamics in mangrove ecosystems: a review. Aquat. Bot., v. 89, n. 2, p. 201-219, 2008

LANGSTON, W. J.; POPE, N. D. Determinants of TBT adsorption and desorption in estuarine sediments. Mar. Pollut. Bull., v. 31, n. 1/3, p. 32-43, 1995. [Proceedings of the Third International Conference on Trace Metals in the Aquatic Environment].

LAFLEUR, A. D.; SCHUG, K. A. A review of separation methods for the determination of estrogens and plasticsderived estrogen mimics from aqueous systems. Anal. Chim. Acta, v. 696, n. 1/2, p. 6-26. 2011. 
LEWIS, J. A. Marine biofouling and its prevention on underwater surfaces. Mater. Forum, v. 22, p. 41-61, 1998.

LIMAVERDE, A. M.; WAGENER, A. L. R.; FERNANDES, M. A.; SCOFIELD, A. L.; COUTINHO, R. Stramonita haemastoma as a bioindicator for organotin contamination in coastal environments. Mar. Environ. Res., v. 64, n. 3, p. 384-398, 2007.

MARTI, N.; AGUADO, D.; SEGOVIA-MARTINEZ, L.; BOUZAS, A.; SECO, A. Occurrence of priority pollutants in WWTP effluents and Mediterranean coastal waters of Spain. Mar. Pollut. Bull., v. 62, n. 3, p. 615$625,2011$.

MATTHIESSEN, P.; GIBBS, P. E. Critical appraisal of the evidence for tributyltin-mediated endocrine disruption in mollusks. Environ. Toxicol. Chem., v, 17, n. 1, p. 3743, 1998.

MORCILLO, Y.; PORTE, C. Evidence of endocrine disruption in clams - Ruditapes decussata -transplanted to a tributyltin-polluted environment. Environ. Pollut., v. 107 , n. 1, p. 47-52, 2000.

MORTON, B. Recovery from imposex by a population of the dogwhelk, Nucella lapillus (Gastropoda: Caenogastropoda), on the southeastern coast of England since May 2004: a 52-month study. Mar. Pollut. Bull., v. 58, n. 10, p. 1530-1538, 2009.

MURAI, R.; SUGIMOTO, A.; TANABE, S.; TAKEUCHI, I. Biomagnification profiles of tributyltin (TBT) and triphenyltin (TPT) in Japanese coastal food webs elucidated by stable nitrogen isotope ratios. Chemosphere, v. 73, n. 11, p. 1749-1756, 2008.

NAKANISHI, T. Potential toxicity of organotin compound via nuclear receptor signalling in mammals. J. Health Sci., v. 53, p. 1-9, 2007.

ORTIZ, N.; RÉ, M. E. First report of pseudohermaphroditism in cephalopods. J. Mollus. Stud., v. 72, n. 3, p. 321-323, 2006.

OEHLMANN, J.; SCHULTE-OEHLMANN, U.; TILLMANN, M.; MARKERT, B. Effects of endocrine disruptors on prosobranch snails (Mollusca: Gastropoda) in the laboratory. Part I: Bisphenol A and octylphenol as xeno-estrogens. Ecotoxicology, v. 9, n. 6, p. 383-397, 2000.

OEHLMANN, J.; DI BENEDETTO, P.; TILLMANN, M.; DUFT, M.; OETKEN, M.; SCHULTE-OEHLMANN, U. Endocrine disruption in prosobranch molluscs: evidence and ecological relevance. Ecotoxicology, v. 16, n. 1, p. 29-43, 2007.

PAMPANIN, D. M.; MARANGON, I.; VOLPATO, E. CAMPESAN, G.; NASCI, C. Stress biomarkers and alkali-labile phosphate level in mussels (Mytilus galloprovincialis) collected in the urban area of Venice (Venice Lagoon, Italy). Environ. Pollut., v. 136, n. 1, p. 103-107, 2005.

PARK, K.; KIM, R.; JUN, J. J.; SHIN, H. C.; LEE, J. S.; CHO, H. S.; LEE, Y. G.; KIM, J.; KWAK, I. S Ecotoxicological evaluation of tributyltin toxicity to the equilateral venus clam, Gomphina veneriformis (Bivalvia: Veneridae). Fish Shellfish Immunol., v. 32, n. 3, p. 426-433, 2012.

PESSOA, I.; FERNANDEZ, M.; TOSTE, R.; DORE, M.; PARAHYBA, M. Imposex in a touristic area in Southeastern Brazilian coast. J. Coastal Res., v. SI56, p.
881-884, 2009. [Proceedings of the 10th International Coastal Symposium, Lisboa, Portugal].

RICCIARDI, F.; MATOZZO, V.; MARIN, M. G. Effects of 4nonylphenol exposure in mussels (Mytilus galloprovincialis) and crabs (Carcinus aestuarii) with particular emphasis on vitellogenin induction. Mar. Pollut. Bull., v. 57, n. 6/12, p. 365-372, 2008.

RUIZ, J. M.; DÍAZ, J.; ALBAINA, N.; COUCEIRO, L.; IRABIEN, A.; BARREIRO, R. Decade-long monitoring reveals a transient distortion of baseline butyltin bioaccumulation pattern in gastropods. Mar. Pollut. Bull., v. 60, n. 6, p. 931-934, 2010.

SANTOS, M. M.; REIS-HENRIQUES, M. A.; GUILLOT, R.; LIMA, D.; FRANCO-DUARTE, R.; MENDES, I.; QUEIRÓS, S.; CASTRO, L. F. Anti-androgenic effects of sewage treatment plant effluents in the prosobranch gastropod Nucella lapillus. Comp. Biochem. Physiol., Part C: Toxicol. Pharmacol., v. 148, n. 1, p. 87-93, 2008

SANTOS, M. M.; ENES, P.; REIS-HENRIQUES, M. A.; KUBALLA, J.; CASTRO, L. F. C.; VIEIRA M. N. Organotin levels in seafood from Portuguese markets and the risk for consumers. Chemosphere, v. 75, n. 5, p. 661-666, 2009.

SCHAEFFER-NOVELLI, Y.; CINTRÓN-MOLERO, G.; SOARES, M. L. G.; DE-ROSA, T. Brazilian mangroves. Aquat. Ecosyst. Health Manage., v. 3, n. 4, p. 561-570, 2000.

SHI, H. H.; HUANG, C. J.; ZHU, S. X.; YU, X. J.; XIE, W. Y. Generalized system of imposex and reproductive failure in female gastropods of coastal waters in mainland China. Mar. Ecol.: Prog. Ser., v. 304, p. 179$189,2005$.

SIAH, A.; MASSON, R.; LOUP, B.; BULTELLE, F; PELLERIN, J.; LEBOULENGER, F.; DANGER, J. M. Receptor activated $\mathrm{C}$ kinase is down-regulated in the male gonad of the marine mollusc bivalve Mya arenaria exposed to tributyltin (TBT). Aquat. Toxicol., v. 83, n. 4, p. 295-305, 2007.

SILVA, S. C.; FERNANDEZ, M. A. S.; SCOTT, P. C. Mapa de sensibilidade ao impacto por anti-incrustantes organoestânicos em Paraty-RJ, utilizando um sistema de informação geográfica. In: CONGRESSO LATINOAMERICANO DE CIÊNCIAS DO MAR COLACMAR, 12., Florianópolis, 2007. Livro de Resumos. Florianópolis, 2007. v. 1. p. 286-286.

SOLOMON, K. R.; CARR, J. A.; DU PREEZ, L. H.; GIESY, J. P.; KENDALL, R. J.; SMITH, E. E.; VAN DER KRAAK, G. J. Effects of atrazine on fish, amphibians, and aquatic reptiles: a critical review. Crit. Rev. Toxicol., v. 38, n. 9, p. 721-772, 2008.

SONAK, S.; PANGAM, P.; GIRIYAN, A.; HAWALDAR, K. Implications of the ban on organotins for protection of global coastal and marine ecology. J. Environ. Manage., v. 90, suppl.1, p. S96-S108, 2009.

SMITH, B. S. Sexuality in the American mud snail, Nassarius obsoletus (Say). J. Mollus. Stud., v. 39, n. 5, p. 377-381, 1971.

SPENCE, S. K.; HAWKINS, S. J.; SANTOS, R. S. Thais haemastoma: an exhibitor of "imposex" and potential biological indicator of tributyltin. Mar. Ecol., v. 11, n. 2, p. $147-156,1990$. 
STRAND, J.; JACOBSEN, J. A. Accumulation and trophic transfer of organotins in a marine food web from the Danish coastal waters. Sci. Total Environ., v. 350, n. $1 / 3$, p. $72-85,2005$.

STROBEN, E.; SCHULTE-OEHLMANN, U.; FIORONI, P.; OEHLMANN, J. A comparative method for easy assessment of coastal TBT pollution by the degree of imposex in Prosobranch species. Haliotis, v. 24, p. 1-12, 1995.

TITLEY-O'NEAL， C.P.; MUNKITTRICK, K.R.; MACDONALD, B.A. The effects of organotin on female gastropods. J. Environ. Monit., v. 13, n. 9, p. 23602388, 2011.

TOSTE, R.; FERNANDEZ, M. A.; PESSOA, I. A.; PARAHYBA, M. A.; DORE, M. P. Organotin pollution at Arraial do Cabo, Rio de Janeiro State, Brazil: increasing levels after the TBT ban. Braz. J. Oceanogr, v. 59 , n. 1, p. 111-117, 2011.

VOULVOULIS, N.; LESTER, J. N. Fate of organotins in sewage sludge during anaerobic digestion. Sci. Total Environ., v. 371, n. 1/3, p. 373-382, 2006.
WISE, A.; O'BRIEN, K.; WOODRUFF, T. Are oral contraceptives a significant contributor to the estrogenicity of drinking water? Environ. Sci. Technol., v. 45, n. 1, p. 51-60, 2011.

YEBRA, D. M.; KIIL, S.; DAM-JOHANSEN, K. Antifouling technology-past, present and future steps towards efficient and environmentally friendly antifouling coatings. Prog. Org. Coat., v. 50, n. 2, p. 75-104, 2004. [Review].

Manuscript received 26 September 2012; revised 18 August 2013; accepted 27 August 2013) 